\title{
PREVALENSI PENYAKIT GIGI DAN MULUT PADA PASIEN DENGAN RIWAYAT GANGGUAN BIPOLAR DI POLI GIGI RUMAH SAKIT JIWA DAERAH SUMATERA UTARA PERIODE JANUARI-MARET 2015
}

\author{
Rina Budiman, Aminah Br.Saragih \\ Jurusan Keperawatan Gigi Poltekkes Kemenkes Medan
}

\begin{abstract}
Abstrak
Bipolar suatu gangguan kejiwaan yang ditandai dengan perubahan mood antara rasa girang yang ekstrim dan depresi yang parah. Prevalensi penyakit gigi dan mulut adalah frekuensi suatu penyakit gigi dan mulut pada suatu jangka waktu tertentu disekelompok masyarakat tertentu. Penelitian prevalensi penyakit gigi dan mulut dilakukan pada pasien dengan riwayat gangguan bipolar. Jenis penelitian yang digunakan adalah penelitian observasional deskripitif dengan pendekatan cross sectional. Data penelitian didapatkan dari rekam medik pasien dengan riwayat gangguan bipolar yang berobat di Poli Gigi Rumah Sakit Jiwa Daerah Sumatera Utara periode Januari-Maret tahun 2015. Hasilnya kemudian dianalisa secara deskriptif dengan memaparkan secara numerik dan grafik. Penelitian secara deskriptif menghasilkan prevalensi penyakit gigi dan mulut pada pasien dengan riwayat gangguan bipolar periode Januari-Maret tahun 2015 sebesar 21.6\%. Prevalensi penyakit gigi dan mulut pada pasien dengan riwayat gangguan bipolar periode Januari-Maret tahun 2015 adalah sebesar $21.6 \%$.
\end{abstract}

Kata kunci : Prevalensi penyakit gigi dan mulut, gangguan bipolar

\section{PENDAHULUAN}

Undang-undang Kesehatan No. 23 tahun 1992 memberikan penjelasan bahwa kesehatan adalah keadaan sehat, baik secara fisik, mental/jiwa, spritual maupun sosial yang memungkinkan setiap orang untuk hidup produktif secara sosial dan ekonomis. Berdasarkan definisi tersebut, sangat jelas diuraikan bahwa kesehatan manusia harus dipandang secara utuh, sehingga indikator "sehat" tidak saja didasarkan pada keadaan fisik yang sehat semata tetapi juga sehat secara mental/jiwa, spiritual dan sosial dengan porsi yang seimbang. Dengan demikian tersirat bahwa kesehatan jiwa merupakan bagian yang tidak dapat dipisahkan (integral) dari kesehatan lainnya, termasuk dengan kesehatan gigi dan mulut.

Definisi kesehatan jiwa menurut Badan Kesehatan Dunia (WHO), adalah kesehatan individu yang tidak hanya bergantung pada tiadanya penyakit tetapi juga keseimbangan psikologis dan fungsi sosialnya (Health is a state of complete physical, mental and social well-being and not merely the absence of disease or infirmity, WHO). Adanya ketidakseimbangan psikologis dan fungsi sosial pada individu menandakan terjadinya gangguan kejiwaan.

Gangguan jiwa merupakan suatu penyimpangan keadaan ideal dari suatu

kesehatan mental yang merupakan indikasi adanya gangguan jiwa. Penyimpangan ini mencakup atas penyimpangan pikiran, perasaan dan tindakan yang menyebabkan individu tidak mampu menyesuaikan diri dengan diri sendiri, orang lain, masyarakat dan lingkungan.
Salah satu gangguan kejiwaan adalah gangguan afeksi (emosi) atau mood (suasana hati/perasaan) atau lebih dikenal dengan istilah Bipolar Disease. Penderita bipolar disease dapat mengalami depresi atau manik (kegirangan dan kesedihan yang tidak wajar), atau dapat bergantian antara manik dan depresif (Atkinson dkk, 1992).

Prevalensi adalah bagian dari studi epidemiologi yang membawa pengertian jumlah orang dalam populasi yang menderita suatu penyakit atau kondisi pada waktu tertentu; pembilang dari angka ini adalah jumlah kasus yang ada dengan kondisi pada waktu tertentu dan penyebutnya adalah populasi total (Dorland, 2002).

Prevalensi penyakit gigi dan mulut pada penderita bipolar disease biasanya luas. Hal ini terkait karena kesehatan gigi dan mulut yang buruk akibat ketidakmandirian penderita bipolar dalam menjaga kebersihan gigi dan mulut. Menurut Dr Clark dalam artikelnya Journal of Canadian Dental Association, selama masa depresi penderita bipolar menunjukkan kemauan yang rendah dalam perawatan kesehatan gigi di rumah, sehingga menyebabkan terjadinya penyakit karies dan periodontal yang cukup tinggi. Sementara pada masa manik, penderita bipolar terlalu bersemangat dalam perawatan kesehatan gigi di rumah, sehingga mereka sering menyikat gigi terlalu keras dan mengakibatkan rentan mengalami abrasi servikal. Tidak hanya itu, penggunaan obat-obat penstabil mood juga mengakibatkan gangguan kesehatan pada mulut seperti terjadinya xerostomia dan stomatitis (www.cda-adc.ca/oral_health). 
Penelitian yang dilakukan di Taiwan oleh Yu Chu pada tahun 2011 pada penderita gangguan jiwa seperti skizofrenia dan bipolar menunjukkan prevalensi karies mencapai 98,5\%. Hal ini menunjukkan bahwa penderita gangguan jiwa umumnya tidak menerima perawatan gigi dengan baik dan memiliki oral higiene yang buruk. Penelitian lain juga dilakukan oleh Zusman et al. pada tahun 2010 yang dilakukan di Israel melaporkan skor DMFT pada pasien yang mengalami gangguan jiwa (skizofrenia, gangguan afektif bipolar, gangguan neurotik dan gangguan mental) sebesar 24,3 $\pm 8,6$, rerata gigi karies sebesar 2,84 \pm 4 , dan rerata kehilangan gigi (missing teeth) sebesar 20 $\pm 11,0$. Kecenderungan penderita gangguan kejiwaan salah satunya akan mengakibatkan ketidakmampuan untuk merawat gigi sendiri termasuk merawat kebersihan mulutnya.

Pada survey awal yang dilakukan peneliti di RSJ PROVSU didapat informasi bahwa belum pernah dilakukannya penelitian sehubungan dengan kesehatan gigi dan mulut yang dilakukan oleh mahasiswa terhadap penderita gangguan jiwa, khususnya penderita bipolar.

Berdasarkan uraian di atas maka peneliti merasa tertarik untuk meneliti masalah prevalensi penyakit gigi dan mulut pada pasien dengan riwayat gangguan bipolar di Poli Gigi Rumah Sakit Jiwa Daerah Sumatera Utara Periode Januari-Maret Tahun 2015.

\section{TUJUAN PENELITIAN}

\section{Tujuan Umum}

Untuk mengetahui berapa prevalensi penyakit gigi dan mulut pada pasien dengan riwayat gangguan bipolar di Poli Gigi Rumah Sakit Jiwa Daerah Sumatera Utara Periode Januari-Maret Tahun 2015.

\section{Tujuan Khusus}

1. Untuk mengetahui prevalensi penyakit gigi dan mulut pada pasien dengan riwayat gangguan bipolar berdasarkan jenis kelamin di Poli Gigi Rumah Sakit Jiwa Daerah Sumatera Utara Periode Januari-Maret Tahun 2015.

2. Untuk mengetahui prevalensi penyakit gigi dan mulut pada pasien dengan riwayat gangguan bipolar berdasarkan usia di Poli Gigi Rumah Sakit Jiwa Daerah Sumatera Utara Periode Januari-Maret Tahun 2015.

3. Untuk mengetahui prevalensi penyakit gigi dan mulut pada pasien dengan riwayat gangguan bipolar berdasarkan diagnosa penyakit gigi dan mulut di Poli Gigi Rumah Sakit Jiwa Daerah Sumatera Utara periode Januari-Maret Tahun 2015.

4. Untuk mengetahui jenis-jenis penyakit gigi dan mulut yang umum dijumpai pada pasien dengan riwayat gangguan bipolar di Poli Gigi Rumah Sakit Jiwa Daerah Sumatera Utara Periode Januari-Maret Tahun 2015.

\section{Manfaat Penelitian}

1. Menambah wawasan mengenai prevalensi penyakit, khususnya prevalensi penyakit gigi dan mulut pada pasien dengan riwayat gangguan bipola

2. Memberikan informasi ilmiah yang dapat dijadikan bahan untuk penelitian lebih lanjut.

3. Sebagai masukan bagi pihak poli gigi RSJ PROVSU dan keluarga untuk lebih memperhatikan perawatan kesehatan gigi dan mulut pada pasien dengan riwayat gangguan bipolar.

4. Sebagai bahan informasi dan masukan tentang perlunya perhatian terhadap kesehatan gigi dan mulut penderita gangguan jiwa.

\section{Jenis dan Desain Penelitian}

Dalam penelitian ini jenis penelitian yang digunakan adalah penelitian observasional deskriptif dengan rancangan cross sectional yang bertujuan untuk mengetahui prevalensi penyakit gigi dan mulut pada pasien dengan riwayat gangguan bipolar di Poli Gigi Rumah Sakit Jiwa Daerah Sumatera Utara Periode Januari-Maret tahun 2015.

\section{Lokasi dan Waktu Penelitian \\ Lokasi Penelitian}

Lokasi yang diambil untuk penelitian ini adalah Poli Gigi Rumah Sakit Jiwa Daerah Sumatera Utara Jl.Tali Air No 21 Medan dengan alasan belum pernah dilakukannya penelitian yang berkaitan dengan gigi dan mulut pada pasien dengan riwayat gangguan bipolar.

\section{Waktu Penelitian}

Penelitian ini dilakukan mulai dari bulan Maret 2015 sampai dengan Juli 2015.

\section{Populasi dan Sampel Populasi Penelitian}

Populasi adalah keseluruhan objek penelitian atau objek yang diteliti. (Notoatmodjo S, 2010). Populasi dalam penelitian ini adalah pasien dengan riwayat gangguan bipolar yang berobat ke Poli Gigi Rumah Sakit Jiwa Daerah Sumatera Utara Periode Januari-Maret Tahun 2015 yang berjumlah 206 orang.

\section{Teknik Sampling dan Sampel Penelitian}

Teknik sampling yang digunakan dalam penelitian ini adalah purposive sampling. Purposive sampling adalah teknik untuk menentukan sampel dari populasi berdasarkan ciri-ciri atau sifat tertentu yang berkaitan dengan populasi (Sugiyono, 2005).

Sampel dalam penelitian ini adalah semua pasien dengan riwayat gangguan bipolar yang berobat ke Poli Gigi Rumah Sakit Jiwa Daerah Sumatera Utara Periode Januari-Maret Tahun 2015yang berjumlah 206 orang.

\section{Jenis dan Cara Pengumpulan Data Jenis Pengumpulan Data}

Jenis data yang digunakan pada penelitian ini adalah data sekunder berupa rekam medik yang diperoleh dari data kunjungan pasien yang berobat ke Poli Gigi Rumah Sakit Jiwa Daerah Sumatera Utara periode Januari- 
Maret Tahun 2015 beserta data umum penderita bipolar yang diperoleh dari rekam medik umum Rumah Sakit Jiwa Daerah Sumatera Utara.

\section{Analisis Data}

Analisis data dalam penelitian ini menggunakan analisis deskriptif yaitu memaparkan secara numerik dan grafis (dalam bentuk tabel atau grafik) jumlah kasus pasien yang mengalami penyakit gigi dan mulut pada pasien bipolar di bulan Januari-Maret Tahun 2015.

\section{HASIL PENELITIAN}

Hasil penelitian diperoleh dari data sekunder berupa rekam medik pasien gangguan jiwa yang berobat ke Poli Gigi RSJ PROVSU periode Januari-Maret tahun 2015. Pengumpulan data selain dari rekam medik poli gigi juga diperoleh dari rekam medik umum RSJ PROVSU. Data yang terkumpul dilakukan pengolahan data dan analisa data untuk mendapatkan angka prevalensi penyakit gigi dan mulut dalam bentuk persentase. Selanjutnya hasil penelitian digambarkan melalui tabel dan grafik.

Berdasarkan data rekam medik pasien yang berobat ke Poli Gigi RSJ PROVSU periode Januari-Maret Tahun 2015 didapat 206 diantaranya pasien dengan riwayat gangguan bipolar dari 952 pasien gangguan jiwa lainnya.

Tabel 4.1 Prevalensi Penyakit Gigi dan Mulut Pada Pasien dengan Riwayat Gangguan Bipolar di Poli Gigi RSJ PROVSU Periode Januari-Maret Tahun 2015.

\begin{tabular}{clcc}
\hline No & \multicolumn{1}{c}{ Keterangan } & $\begin{array}{c}\text { Jumlah } \\
\text { Pasien }\end{array}$ & $\%$ \\
\hline 1 & $\begin{array}{l}\text { Pasien mengalami } \\
\text { sakit gigi dan } \\
\text { mulut dengan } \\
\text { riwayat gangguan } \\
\text { bipolar } \\
2\end{array}$ & 206 & 21.6 \\
& $\begin{array}{l}\text { Pasien mengalami } \\
\text { sakit gigi dan } \\
\text { mulut dengan } \\
\text { riwayat gangguan } \\
\text { jiwa lain }\end{array}$ & 746 & 78.4 \\
\hline & & \\
\hline Total & 952 & 100 \\
\hline
\end{tabular}

Dari tabel diatas, dapat dilihat bahwa dari 952 pasien yang berobat ke poli gigi RSJ PROVSU periode Januari-Maret Tahun 2015 didapat prevalensi penyakit gigi dan mulut pada pasien dengan riwayat gangguan bipolar $21.6 \%$ dan prevalensi penyakit gigi dan mulut pada pasien dengan riwayat gangguan jiwa lainnya sebesar $78.4 \%$.
Tabel 4.2 Tabel distribusi Prevalensi Penyakit Gigi dan Mulut Pada Pasien dengan Riwayat Gangguan Bipolar berdasarkan Jenis Kelamin di Poli Gigi RSJ PROVSU Periode Januari-Maret Tahun 2015.

\begin{tabular}{cccc}
\hline No & Jenis Kelamin & $\begin{array}{l}\text { Pasien Bipolar yang } \\
\text { Terkena Penyakit } \\
\text { Gigi dan Mulut }\end{array}$ & $\%$ \\
\hline 1 & Perempuan & 70 & 34 \\
2 & Laki-laki & 136 & 66 \\
\hline & Total & 206 & 100 \\
\hline
\end{tabular}

Berdasarkan tabel diatas, dari 206 pasien dengan riwayat gangguan bipolar yang berobat ke poli gigi RSJ PROVSU periode Janari-Maret Tahun 2015 didapat prevalensi penyakit gigi dan mulut pasien riwayat gangguan bipolar berdasarkan jenis kelamin. Prevalensi penyakit gigi dan mulut pada pasien dengan gangguan riwayat bipolar berjenis kelamin perempuan $34 \%$ dan berjenis kelamin laki-laki $66 \%$.

Tabel 4.3 Tabeldistribusi Penyakit Gigi dan Mulut Pada Pasien dengan Riwayat Gangguan Bipolar berdasarkan Usia di Poli Gigi RSJ PROVSU Periode Januari-Maret Tahun 2015.

\begin{tabular}{cccc}
\hline No & $\begin{array}{c}\text { Usia } \\
\text { (Tahun) }\end{array}$ & $\begin{array}{c}\text { Pasien Bipolar yang } \\
\text { Terkena Penyakit Gigi } \\
\text { dan Mulut }\end{array}$ & $\%$ \\
\hline 1 & $10-19$ & 18 & 8.7 \\
2 & $20-29$ & 56 & 27.2 \\
3 & $30-39$ & 59 & 28.6 \\
4 & $40-49$ & 39 & 18.9 \\
5 & $50-59$ & 28 & 13.6 \\
6 & $60>$ & 6 & 2.9 \\
\hline & Total & 206 & 100 \\
\hline
\end{tabular}

Berdasarkan tabel diatas, dari 206 pasien dengan riwayat gangguan bipolar yang berobat ke poli gigi RSJ PROVSU Periode Janari-Maret Tahun 2015 didapat prevalensi penyakit gigi dan mulut pasien riwayat gangguan bipolar berdasarkan usia. Prevalensi penyakit gigi dan mulut pada pasien bipolar berusia 10-19 tahun sebesar 8.7\%, 20-29 tahun sebesar 27.2\%, 30-39 tahun sebesar $28.6 \%$, 40-49 tahun sebesar 18.9\%, 50-59 tahun sebesar $13.6 \%$ dan $60>$ sebesar $2.9 \%$. 
Tabel 4.4 Tabel Distribusi Kasus Penyakit Gigi dan Mulut Pada Pasien dengan Riwayat Gangguan Bipolar berdasarkan Diagnosa Penyakit Gigi dan Mulut di Poli Gigi RSJ PROVSU Periode Januari-Maret Tahun 2015.

\begin{tabular}{cccc}
\hline No & $\begin{array}{c}\text { Diagnosa } \\
\text { Penyakit }\end{array}$ & $\begin{array}{c}\text { Kasus Penyakit } \\
\text { Gigi dan Mulut } \\
\text { Pada Pasien Bipolar }\end{array}$ & $\%$ \\
\hline 1 & Karies & 104 & 14.1 \\
2 & Radix & 92 & 12.5 \\
3 & Pulpitis & 62 & 8.4 \\
4 & Abses & 38 & 5.2 \\
5 & Gangren & 49 & 6.6 \\
6 & Calculus & 101 & 13.7 \\
7 & Gingivitis & 86 & 11.7 \\
8 & Impacted & 13 & 1.8 \\
9 & Mobility & 94 & 12.8 \\
10 & Stomatitis & 97 & 13.2 \\
\hline & Total & 736 & 100 \\
\hline
\end{tabular}

Berdasarkan tabel diatas, dari 206 pasien dengan riwayat gangguan bipolar yang berobat ke poli gigi RSJ PROVSU Periode Januari-Maret Tahun 2015 didapat jumlah kasus penyakit gigi dan mulut sebanyak 736 . Untuk prevalensi tertinggi berada pada kasus karies dengan persentase $14,1 \%$ dan yang terendah pada kasus impaksi (impacted) dengan persentase $1,8 \%$.

\section{PEMBAHASAN}

Berdasarkan hasil penelitian yang telah dilakukan di poli gigi Rumah Sakit Jiwa Daerah Sumatera Utara periode Januari-Maret tahun 2015 didapat prevalensi penyakit gigi dan mulut pada pasien dengan riwayat gangguan bipolar sebanyak $21.6 \%$ yang dapat dilihat pada Tabel 4.1. Sedangkan prevalensi nasional penyakit gigi dan mulut di Indonesia berdasarkan Hasil Riset Kesehatan Dasar (RISKESDAS) 2013 sebanyak 25,9\%. Prevalensi penyakit gigi dan mulut pada penderita bipolar ini hampir setara dengan prevalensi nasional penyakit gigi dan mulut. Hal ini dikarenakan orang dengan gangguan jiwa seperti gangguan bipolar lebih rentan mengalami masalah kesehatan gigi dan mulut daripada orang yang tidak mengalami gangguan jiwa. Hal ini diperkuat dengan penelitian yang telah dilakukan oleh Universitas Florida Fakultas Kedokteran Gigi mengenai masalah kesehatan gigi dan mulut yang terjadi pada penderita bipolar, dimana penderita bipolar mengalami banyak masalah kesehatan gigi dan mulut baik pada masa manik ataupun depresi (https://cme.ucsd.edu/dhealth/courses/mood.html).

Prevalensi penyakit gigi dan mulut pada pasien dengan riwayat gangguan bipolar berjenis kelamin lakilaki sebesar 66\% sedangkan untuk berjenis kelamin perempuan sebesar $34 \%$. Berdasarkan hasil penelitian didapat bahwa prevalensi penyakit gigi dan mulut pada penderita bipolar berjenis kelamin lelaki lebih tinggi daripada penderita bipolar berjenis kelamin perempuan.

Prevalensi penyakit gigi dan mulut pada pasien dengan riwayat gangguan bipolar berdasarkan usia didapat prevalensi tertinggi pada rentang usia 30-39 tahun sebesar 28.6\%, dan pada pada urutan kedua pada rentan usia 20-29 tahun sebesar $27.2 \%$ sedangkan prevalensi terendah pada rentang usia 60> sebesar 2.9\%. Hal ini mendekati pernyataan prevalensi gangguan depresi pada populasi dunia terbanyak pada usia produktif yaitu 20-50 tahun, dimana hasil penelitian Wenning dkk pada tahun 2010, didapatkan manusia terbanyak adalah 16-24 tahun sebesar $58,6 \%$ (Wening, 2010). Sementara pada gangguan bipolar juga mengalami episode depresi. Pada episode depresi, permasalahan kesehatan gigi dan mulut yang menjadi paling utama adalah kebersihan gigi dan mulut yang tidak baik yang dialami penderita bipolar. Penderita bipolar cenderung murung dan tidak bergairah dalam melakukan aktivitas sehari-hari. Hal inilah menjadikan penderita bipolar apatis dan tidak kooperatif dalam menerima perawatan kesehatan gigi dan mulut.

Untuk prevalensi kasus penyakit gigi dan mulut pada pasien dengan riwayat gangguan bipolar berdasarkan diagnosa didapat bahwa penyakit karies mendapatkan urutan tertinggi dengan persentase sebesar 14.2 dan kasus impaksi mendapat uutan terendah sebesar $1.8 \%$. Bila dilihat data dari Tabel 4.4 selisih persentase untuk masingmasing kasus penyakit gigi dan mulut yang ada tidak besar. Ini menandakan bahwa pasien dengan riwayat gangguan bipolar mengalami banyak masalah dengan kesehatan gigi dan mulut mereka. Menurut Prof. Steve Kesley dalam laporannya British Journal of Psychiatry, seorang ilmuwan dari University of Queensland yang melakukan penelitian masalah kesehatan gigi dan mulut pada gangguan jiwa seperti bipolar, pikun, skizoprenia, psikotik dan gangguan mental mengungkapkan bahwa seseorang yang memiliki masalah kejiwaan 3 kali lebih berisiko mengalami gigi tanggal dan 6 kali lebih rentan mengalami gigi keropos (www.medicalnewtoday.com)

Selanjutnya masalah kesehatan gigi dan mulut yang sering dialami pasien dengan riwayat bipolar adalah terjadinya kerusakan jaringan keras gigi seperti abrasi karena terlalu kuat menyikat gigi pada saat episode mayor manik. Dan gigi yang mengalami abrasi memberikan ruang bagi plak menempel sehingga menimbulkan masalah kesehatan gigi nantinya. Selain itu, penggunaan obat terapi penstabil mood bagi pasien dengan riwayat gangguan bipolar ternyata berakibat buruk terhadap kesehatan gigi dan mulut. Penggunaan obat lithium dalam jangka panjang menyebabkan produksi saliva menurun sehingga mukosa mulut kering (xerostomia). Produksi saliva yang sedikit berisiko tinggi terhadap terjadinya masalah kesehatan gigi lainnya dan bahkan terjadinya peradangan pada mukosa mulut atau stomatitis (https://cme.ucsd.edu/dhealth/courses/mood).

\section{SIMPULAN}

Berdasarkan hasil penelitian yang telah dilakukan, maka dapat diambil kesimpulan sebagai berikut:

1. Prevalensi penyakit gigi dan mulut pada pasien dengan riwayat gangguan bipolar di Poli Gigi Rumah Sakit Jiwa Daerah Sumatera Utara Periode Januari-Maret Tahun 2015 sebesar $21.6 \%$. 
2. Prevalensi penyakit gigi dan mulut pada pasien dengan riwayat gangguan jiwa lainnya di Poli Gigi Rumah Sakit Jiwa Daerah Sumatera Utara periode Januari-Maret Tahun 2015 sebesar $78.4 \%$.

3. Prevalensi penyakit gigi dan mulut pada pasien dengan riwayat gangguan bipolar di Poli Gigi Rumah Sakit Jiwa Daerah Sumatera Utara Periode Januari-Maret Tahun 2015 berdasarkan jenis kelamain, yaitu laki-laki sebesar $66 \%$ dan perempuan $34 \%$.

4. Prevalensi penyakit gigi dan mulut pada pasien dengan riwayat gangguan bipolar di Poli Gigi Rumah Sakit Jiwa Daerah Sumatera Utara Periode Januari-Maret Tahun 2015 berdasarkan usia, yaitu rentang usia 10-19 tahun sebesar $8.7 \%, 20-29$ tahun sebesar $27.2 \%$, 30-39 tahun sebesar 28.6\%, 40-49 tahun sebesar $18.9 \%$, 50-59 sebesar $13.6 \%$ dan 60> sebesar $2.9 \%$.

5. Prevalensi kasus penyakit gigi dan mulut pada pasien dengan riwayat gangguan bipolar di Poli Gigi Rumah Sakit Jiwa Daerah Sumatera Utara periode Januari-Maret Tahun 2015 berdasarkan diagnosa penyakit gigi dan mulut, yaitu karies sebesar $14.1 \%$, radix sebesar $12.5 \%$, pulpitis sebesar $8.4 \%$, abses sebesar $5.2 \%$, gangren pulpa sebesar $6.6 \%$, calculus sebesar $13.7 \%$, gingivitis sebesar $11.7 \%$, impaksi (impacted) sebesar 1.8\%, mobility sebesar $12.8 \%$ dan stomatitis sebesar $13.2 \%$.

\section{SARAN}

1. Diharapkan agar dilaksanakan penelitian lebih lanjut mengenai prevalensi penyakit gigi dan mulut pada pasien dengan riwayat gangguan bipolar di Poli Gigi Rumah Sakit Jiwa Daerah Sumatera Utara, dengan begitu dapat dibuat suatu perencanaan lebih lanjut.

2. Diharapkan kepada pihak Rumah Sakit Jiwa Daerah Sumatera Utara, khususnya Poli Gigi untuk lebih berperan aktif dalam meningkatkan dan memberikan perawatan kesehatan gigi dan mulut pada pasien dengan gangguan kejiwaan bipolar, baik dari segi pendekatan personal terhadap pasien maupun upaya promotif, preventif, kuratif dan rehabilitatif.
3. Diharapkan kepada pihak keluarga dari pasien untuk lebih perduli terhadap kesehatan gigi dan mulut pasien melalui pengawasan dan bimbingan dalam menjaga kesehatan gigi dan mulut pasien

\section{DAFTAR PUSTAKA}

Alamsyah RM, Situmorang N. 2005. Dampak Gigi Molar Tiga Mandibula Impaksi Terhadap Kualitas Hidup Manusia. Universitas Sumatera Barat: Dentika Dental Journal

Dorland, W.A. Newman.2002.Kamus Kedokteran Dorland Edisi 29. ECG: Jakarta

Drayton, S.J., \& Weinstein, B.,2008, Bipolar Disorder, dalam Dipiro, J.T., Talbert, R.L., Yee, G.C., Matzke, G.R., Wells, B.G., Posey, L.M., (Eds), Pharmacotheraphy A Pathophysiologic Approach, 7th Edition, 1174-1181, New York: McGraw Hill Companies, Inc.

Harris, N.O and Christen, A.G. 1995. Primary dentistry.4th ed.Conecticut: Appleton \& Lange

Huis, 1984. Ilmu Kedokteran Gigi Pencegahan (terj), Gadjah Mada University Press: Yogyakarta

Kidd E. 2005. Essential of Dental Caries. 3rd ed. London: Oxford University Press

Marwati E \& Chahya R, Maret 2004. Penatalaksanaan Penderita Stomatitis Aftosa Rekuren. Jakarta: Majalah Kedokteran Gigi

Nevid,J.F., dkk. 2005. Psikologi Abnormal. Jakarta: Erlangga

Notoatmodjo,S. 2010. Metodologi Penelitian Kesehatan. Jakarta: Rineka Cipta

Pintauli, S dan Taizo.H., 2008. Menuju Gigi dan Mulut Sehat. Medan: USU PRESS

Pratiwi, D., 2007. Gigi Sehat. Jakarta: Kompas Media Nusantara

Ramadhan, A.G. 2010. Serba-serbi Kesehatan Gigi dan Mulut. Bukane: Jakarta

Shafer. 1983. William G. A Textbook of Oral Pathology, 4th ed.W.B.Saunders Company: Philadelpia

Sudiono J, 2003 Ilmu Patologi. Jakarta: EGC

www.academia.edu

www.cda-adc.ca/oral health

https://cme.ucsd.edu/dhealth/courses/mood.html

http://gaea-flossn.weebly.com/bipolar-disorder

www.infogigi.com 